Hal. 41 - 49

\title{
PENGARUH MOTIVASI, PENGEMBANGAN KARIR TERHADAP KEPUASAN KERJA DAN KINERJA PERAWAT DI RUMAH SAKIT dr. SOEBANDI JEMBER
}

\author{
Raditya Bagus Evanda \\ Program Studi Magister Manajemen Universitas Jember
}

\begin{abstract}
Nurse of dr. Soebandi Hospital as duty bearers geared towards improving the quality of human resources, and the result will have an impact on job performance. Job performance a good nurses is a desirable thing in every hospital, due to the good performance, the hospital will achieve the goals effectively and efficiently. The determining factor to improve achievement nurses is satisfaction of work and motivation. In this research, the population was all the nurse civil servants in $d r$. Soebandi Hospital Jember, some 194 people from each strata is taken proportionately sample size with the total sample who was elected 131 nurses with a leeway $5 \%$ using Slovin opinion. The sample collection in this study was conducted using stratified random sampling. To test the instruments used in extracting the data in this research, it is necessary to test the validity and reliability of the instrument with the methods of analysis data normality test, and path analysis. The results of the analysis are: (1) motivation has direct and significant impact on job satisfaction of nurses at dr. Soebandi Hospital, Jember; (2) the career development has direct and significant impact on job satisfaction of nurses at dr. Soebandi Hospital, Jember; (3) motivation has direct and significant impact on the nurses performance at dr. Soebandi Hospital, Jember; (4) the career development has direct and significant impact on the nurses performance at dr. Soebandi Hospital, Jember; (5) The job satisfaction has direct and significant impact on the nurses performance at hospital dr. Soebandi Jember.
\end{abstract}

Keywords: motivation, career development, job satisfaction, Nurses

\begin{abstract}
Abstrak: Perawat Rumah Sakit dr. Soebandi sebagai pembawa tugas diarahkan untuk meningkatkan kualitas sumber daya manusia, dan hasilnya akan berdampak pada kinerja. Kinerja kerja perawat yang baik adalah hal yang diinginkan di setiap rumah sakit, karena kinerjanya bagus, rumah sakit akan mencapai tujuan secara efektif dan efisien. Faktor penentu untuk meningkatkan prestasi perawat adalah kepuasan kerja dan motivasi. Dalam penelitian ini, populasi adalah seluruh pegawai perawat di dr. Rumah Sakit Soebandi Jember, sekitar 194 orang dari masing-masing strata diambil secara proporsional dengan ukuran sampel dengan jumlah sampel 131 perawat dengan kelonggaran 5\% dengan menggunakan pendapat Slovin. Pengumpulan sampel dalam penelitian ini dilakukan dengan menggunakan stratified random sampling. Untuk menguji instrumen yang digunakan dalam penggalian data dalam penelitian ini, perlu dilakukan uji validitas dan reliabilitas instrumen dengan metode analisis data uji normalitas, dan analisis jalur. Hasil analisisnya adalah: (1) motivasi berpengaruh langsung dan signifikan terhadap kepuasan kerja perawat pada dr. Rumah Sakit Soebandi, Jember; (2) perkembangan karir berpengaruh langsung dan signifikan terhadap kepuasan kerja perawat di dr. Rumah Sakit Soebandi, Jember; (3) motivasi berpengaruh langsung dan signifikan terhadap kinerja perawat di dr. Rumah Sakit Soebandi, Jember; (4) perkembangan karir berpengaruh langsung dan signifikan terhadap kinerja perawat di dr. Rumah Sakit Soebandi, Jember; (5) Kepuasan kerja berpengaruh langsung dan signifikan terhadap kinerja perawat di rumah sakit dr. Soebandi Jember.
\end{abstract}

Kata kunci: Motivasi, Pengembangan Karir, Kepuasan Kerja, dan Perawat 


\section{Pendahuluan}

Pegawai negeri adalah pegawai yang telah memenuhi syarat yang ditentukan, diangkat oleh pejabat yang berwenang dan diserahi tugas dalam suatu jabatan negeri, atau diserahi tugas negara lainnya, dan digaji berdasarkan peraturan perundangundangan yang berlaku. Pegawai Negeri Sipil khususnya perawat PNS pada Rumah Sakit dr. Soebandi selaku Sumber Daya Manusia jelas mengemban tugas sesuai dengan tugas pokok dan fungsinya guna memberikan pelayanan kepada masyarakat. Perawat Rumah Sakit dr. Soebandi selaku pengemban tugas diarahkan untuk meningkatkan kualitas sumber daya manusia dan nantinya juga berdampak pada prestasi kerja. Prestasi kerja perawat yang baik adalah suatu hal yang diinginkan setiap rumah sakit, karena dengan prestasi kerja yang baik, rumah sakit akan mencapai tujuan secara efektif dan efisien. Saeful Faroji, (2013) mengatakan bahwa pentingnya kepuasan kerja dapat dijadikan indikasi peningkatan atau penurunan prestasi kerja. Salah satu faktor pendorong kepuasan kerja adalah adanya pengembangan karir yang jelas.

Jika pengembangan karir merupakan hak bagi PNS khusunya Perawat Rumah Sakit dr. Soebandi Kabupaten Jember maka disiplin kerja adalah kewajiban pegawai yang harus ditaati. Meningkatnya disiplin kerja akan meningkatkan prestasi kerja sebanding dengan menurunnya kedisiplinan kerja jelas akan menurunkan prestasi kerja dan menurunkan produktivitas organisasi atau instansi itu sendiri. (Ari Sucipta, 2013). Salah satu faktor yang berkaitan dengan prestasi kerja perawat adalah kepuasan kerja perawat. Kepuasan kerja (job satisfaction) adalah keadaan emosional perawat yang terjadi maupun tidak terjadi, titik temu antara nilai balas jasa kerja perawat dan rumah sakit dengan tingkat nilai balas jasa yang memang diinginkan oleh perawat yang bersangkutan (Martoyo, 2009:142). Berkenaan dengan masalah kepuasan kerja, ada beberapa faktor yang memengaruhi kepuasan kerja karyawan. Gilmer dalam Wahyudin (2009) menyebutkan faktor-faktor yang memengaruhi kepuasan kerja adalah kondisi pengembangan karir, motivasi dan pekerjaan, kesempatan untuk maju, keamanan kerja, gaji, aspek sosial dalam pekerjaan, komunikasi dan fasilitas. Sementara itu, Heidjrachman dan Handoko (2006:194)

Motivasi berpengaruh terhadap kepuasan karyawan. Motivasi merupakan suatu penggerak yang berasal dari diri sendiri. Inilah motor utama dalam menciptakan kinerja yang tinggi. Tanpa motivasi yang tulus, tidak mungkin tercipta kinerja yang tinggi. Karyawan yang memiliki motivasi yang tinggi dalam aktivitas pekerjaannya akan lebih 
mudah dalam mencapai kepuasan kerjanya. Hal itu disebabkan adanya dorongan untuk lebih baik dalam menyelesaikan pekerjaan yang telah diberikan. Pelaksanaan Manajemen Sumber Daya Manusia yang baik, diyakini dapat meningkatkan efektifitas organisasi serta memberi keuntungan walaupun dalam suasana penuh persaingan (Dharma, 2007:40). Salah satu bentuk pelaksanaan Manajemen Sumber Daya Manusia yang baik dimana perusahaan harus mampu menciptakan suasana kerja yang akan menimbulkan kepuasan kerja sehingga nantinya akan mendapatkan hasil yang lebih optimal. Adanya hasil yang optimal pada akhirnya akan berdampak pada peningkatan prestasi kerja karyawan.

Motivasi didefinisikan sebagai keadaan dalam pribadi seseorang yang mendorong keinginan individu untuk melakukan kegiatan-kegiatan tertentu guna mencapai suatu tujuan. Motivasi pada seseorang akan mewujudkan suatu perilaku yang diarahkan pada pencapaian tujuan mencapai sasaran kepuasan (Reksohadiprojo dan Handoko, 2006). Motivasi merupakan upaya bersama dengan sifat-sifat individual dan bantuan keorganisasian. Seseorang yang sangat termotivasi yaitu orang yang melaksanakan upaya substansial guna menunjang tujuan produksi kesatuan kerjanya dan organisasi di mana ia bekerja

Seseorang yang tidak termotivasi hanya memberikan upaya minimum dalam hal bekerja. Konsep motivasi merupakan sebuah konsep penting dalam studi tentang prestasi kerja individual. Dengan kata lain, motivasi merupakan sebuah determinan penting bagi kinerja individual. Jelas kiranya, bahwa motivasi bukan satu-satunya determinan, karena masih ada variabel-variabel lain yang turut mempengaruhinya seperti: Upaya (kerja) yang dikerahkan, Kemampuan orang yang bersangkutan, Pengalaman (kerja) sebelumnya. Motivasi dapat bersifat positif ataupun negatif. Motivasi positif yang kadang-kadang dinamakan orang "motivasi yang mengurangi perasaan cemas" (anxiety reducing motivation) atau "pendekatan wortel" (the carrot approach) di mana orang ditawari sesuatu yang bernilai (misalnya imbalan berupa uang, pujian, dan kemungkinan untuk menjadi karyawan tetap) apabila kinerjanya memenuhi standar yang ditetapkan.

Kepuasan kerja dalam suatu institusi atau organisasi merupakan suatu faktor penting, karena banyak penelitian menunjukkan bahwa kepuasan kerja berhubungan dengan keinginan berpindah. Tetapi kadang kepuasan kerja tidak diperhatikan karena secara umum menyangkut sikap seseorang mengenai pekerjaannya. Menurut Koesmono (2005:219), kepuasan kerja adalah the positive and negative feelings and 
attitudes about one's job atau dapat dikatakan bahwa kepuasan kerja merupakan perasaan dan perilaku negatif dan positif tentang suatu pekerjaan. Perasaan yang berhubungan dengan pekerjaan melibatkan aspek-aspek seperti upah atau gaji yang diterima, kesempatan pengembangan karier, hubungan dengan karyawan lainnya, penempatan kerja, jenis pekerjaan, struktur organisasi institusi, ataupun mutu pengawasan. Sedangkan perasaan yang berhubungan dengan dirinya, antara lain umur, kondisi kesehatan, kemampuan, dan pendidikan. Karena itu maka kepuasan kerja menyangkut perasaan yang bukan berarti tidak perlu diperhatikan sebab kepuasan kerja akan tercermin pada hasil pekerjaan. Oleh sebab itu organisasi harus menaruh perhatian lebih pada kepuasan kerja.

Lower dan Porter dalam Indra Wijaya (1999) menyebutkan bahwa prestasi kerja merupakan perpaduan antara motivasi dan kemampuan dalam menyelesaikan pekerjaan atau prestasi seseorang tergantung kepada keinginan untuk berprestasi dan kemampuan yang bersangkutan untuk melakukannya. Motif berprestasi merupakan salah satu dari tiga motif pada diri manusia dan secara lengkap menurut Robbins (2004), yaitu motif berprestasi, motif untuk berafiliasi, dan motif untuk berkuasa. Disebutkan bahwa motif berprestasi tercermin pada orientasinya terhadap tujuan dan pengabdian demi tercapainya tujuan dengan sebaik-baiknya. Setiap pencapaian prestasi diikuti perolehan yang mempunyai nilai bagi karyawan yang bersangkutan, baik berupa upah, promosi, teguran, maupun pekerjaan yang lebih baik. Hal ini tentunya memiliki nilai yang berbeda bagi orang yang berbeda. Masalahnya adalah bagaimana atasan menghargai prestasi kerja para karyawan sehingga dapat memotivasi. Dharma (2007), pengukuran prestasi kerja mempertimbangkan (1) kuantitas, yaitu jumlah pekerjaan yang harus diselesaikan; (2) kualitas, yaitu mutu yang dihasilkan dan (3) ketepatan waktu, yaitu kesesuaiannya dengan waktu yang telah direncanakan.

Pengembangan karier adalah suatu pendekatan formal yang diambil dan digunakan organisasi untuk menjamin, agar orang-orang dengan kecakapan dan pengalaman yang layak yang tersedia ketika dibutuhkan (Dharma, 2007: 17). Perencanaan dan pengembangan karier pada dasarnya meliputi dua proses utama yaitu perencanaan karier dan manajemen karier. Perencanaan karier memusatkan perhatiannya pada pekerja, sedangkan manajemen karier terpusat pada organisasi (Muhaimin, 2004: 92). Keuntungan bagi pekerja dengan adanya perencanaan karier dapat secara lebih baik memahami dan mengidentifikasi tujuan karier yang diinginkan. 
Sementara manfaat bagi organisasi adalah dapat mengkomunikasikan peluang karier pada para pekerja dan memperoleh kesesuaian yang lebih baik antara aspirasi pekerja dengan peluang organisasi.

Oleh karena itu, Rumah Sakit dr. Soebandi dengan berbagai karakter dan kondisi perawat, untuk menyatukan visi, misi dan tujuan institusi harus mampu memahami karakter sumber daya manusia terutama yang berhubungan dengan faktor-faktor SDM yang berpengaruh terhadap kepuasan dan prestasi kerja karyawan. Dengan pengelolaan Manajemen Sumber Daya Manusia yang baik dapat menjadi penentu strategi institusi dalam menghadapi permasalahan yang timbul di era globalisasi ini.

Tujuan penelitian ini adalah: (1) menguji pengaruh motivasi terhadap kepuasan kerja perawat Rumah Sakit dr. Soebandi Jember; (2) menguji pengaruh pengembangan karier terhadap kepuasan kerja perawat Rumah Sakit dr.Soebandi Jember; (3) menguji pengaruh motivasi terhadap kinerja perawat Rumah Sakit dr. Soebandi Jember; (4) menguji pengaruh pengembangan karier terhadap kinerja perawat Rumah Sakit dr. Soebandi Jember; dan (5) menguji pengaruh kepuasan kerja terhadap kinerja perawat Rumah Sakit dr. Soebandi Jember.

\section{Metodologi}

Penelitian ini dirancang sebagai penelitian eksplanatori untuk menjelaskan pengaruh motivasi, pengembangan karier serta terhadap kepuasan kerja dan prestasi kerja perawat. Untuk memperoleh gambaran yang utuh tentang gambaran tersebut, penelitian ini beranjak dari data deskriptif yang berhubungan dengan pokok bahasan yang kemudian dianalisis dengan menggunakan analisis jalur.

Dalam penelitian ini yang menjadi populasi adalah seluruh perawat PNS di Rumah Sakit dr. Soebandi Jember sejumlah 194 orang. Pengambilan sampel dalam penelitian ini dilakukan dengan metode stratified random sampling, yaitu penarikan sampel dengan membagi dalam empat strata, yaitu: 1. PNS Golongan IV; 2. PNS Golongan III; 3. PNS Golongan II; 4. PNS Golongan I di Rumah Sakit dr. Soebandi Jember.Selanjutnya dari masing-masing strata diambil ukuran sampel secara proposional dengan jumlah sampel yang terpilih 131 orang perawat diperoleh dari 194 orang perawat dengan persen kelonggaran 5\% menggunakan pendapat Slovin (Sevilla, 1993:161). 
Pengumpulan data dilakukan melalui beberapa cara meliputi: (1) Observasi, adalah cara pengumpulan data dengan melakukan pencatatan secara cermat dan sistematik; (2) Wawancara, yaitu mengadakan tanya jawab secara langsung dengan responden maupun pihak-pihak lain yang terkait; (3) Kuesioner, yaitu dengan memberikan daftar pertanyaan kepada responden.

Metode analisis data yang digunakan untuk penelitian ini: (1) Uji Normalitas Data Pengujian kenormalan data dilakukan untuk mengetahui bahwa data yang dianalisis berdistribusi normal atau tidak. Data yang berdistribusi normal dianalisis dengan regresi berganda. Uji kenormalan data dapat dilakukan dengan menggunakan program SPSS. Dalam penelitian ini, uji kenormalan data dilakukan dengan Kolmogorov-Smirnov test dengan menetapkan derajat keyakinan ( $\alpha$ ) sebesar 5\%. Uji ini digunakan untuk menguji variabel independent dan variabel dependen yang tidak diketahui distribusinya. Apabila distribusinya tidak normal maka data tersebut terlebih dahulu dinormalkan dengan melogaritma naturalkan data yang tidak berdistribusi normal (Santoso, 2009:171). Kriteria pengambilan keputusannya adalah: Signifikansi > 0,05 berarti data terdistribusi normal,Signifikansi < 0,05 berarti data tidak terdistribusi normal; dan (2) Penelitian ini menggunakan model Analisis Jalur (Path Analysis). Analisis Jalur merupakan alat analisis statistik yang digunakan untuk menguji hipotesis yang diajukan. Model ini digunakan untuk mengetahui seberapa besar variabel-variabel yang mempengaruhi kinerja perawat PNS di Rumah Sakit dr. Soebandi Jember. Dalam analisis jalur terdapat beberapa langkah (Solimun, 2002:48).

\section{Hasil dan Pembahasan}

Pengujian hipotesis yang digunakan pada penelitian adalah menggunakan Analisis Jalur atau Path Analysis dengan program AMOS, uji yang digunakan adalah uji $\mathrm{t}(\mathrm{CR})$, Hasil pengujian hipotesis pengaruh langsung ditampilkan pada tabel 1 berikut:

Tabel 1: Hasil Pengujian Pengaruh Langsung, Tidak Langsung dan Hubungan Total

\begin{tabular}{|c|c|c|c|}
\hline \multicolumn{4}{|c|}{ Pengaruh Langsung } \\
\hline Variabel & $\mathrm{X}_{1}$ & $\mathrm{X}_{2}$ & Z \\
\hline Z & 0,317 & 0,316 & 0,000 \\
\hline $\mathrm{Y}$ & 0,227 & 0,207 & 0,369 \\
\hline \multicolumn{4}{|c|}{ Pengaruh Tidak Langsung } \\
\hline Variabel & $\mathrm{X}_{1}$ & $\mathrm{X}_{2}$ & $\bar{Z}$ \\
\hline Z & 0,000 & 0,000 & 0,000 \\
\hline
\end{tabular}




\begin{tabular}{llll}
\hline $\mathrm{Y}$ & 0,102 & 0,103 & 0,000 \\
\hline Pengaruh Total & & & \\
\hline Variabel & $\mathrm{X}_{1}$ & $\mathrm{X}_{2}$ & $\mathrm{Z}$ \\
\hline $\mathrm{Z}$ & 0,317 & 0,316 & 0,000 \\
\hline $\mathrm{Y}$ & 0,489 & 0,480 & 0,369 \\
\hline
\end{tabular}

Sumber : Hasil analisis

Hasil pengujian tersebut juga disajikan dalam bentuk gambar berupa diagram jalur sebagai berikut.

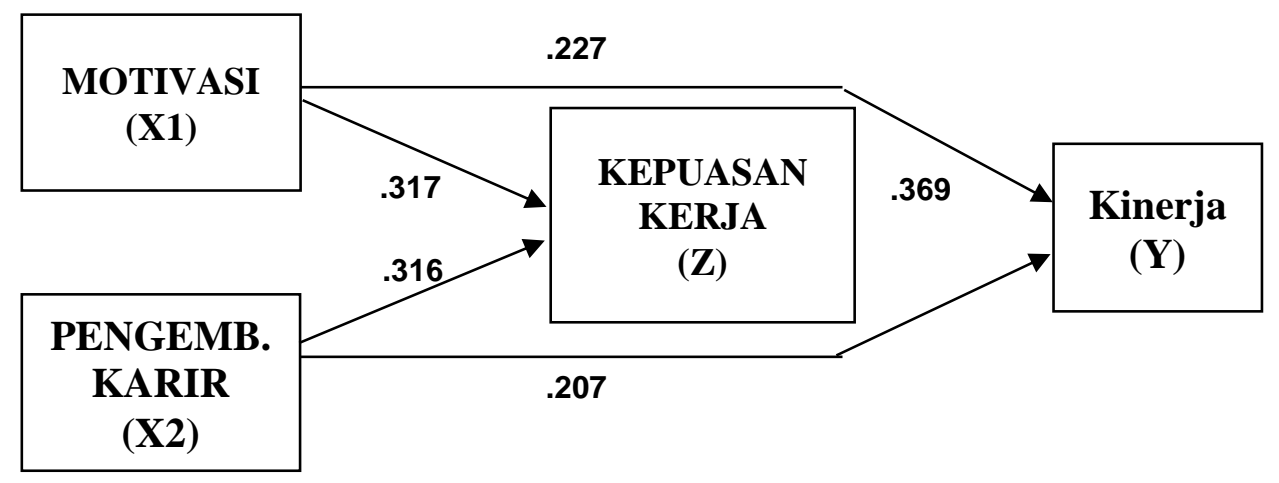

Gambar 1. Diagram Jalur

Berdasarkan Tabel 1 dan Gambar 1. diperoleh hasil analisis penelitian dan pembahasan sebagai berikut.

1. Motivasi berpengaruh secara langsung dan signifikan terhadap kepuasan kerja perawat Rumah sakit dr. Soebandi Jember adalah terbukti. Pengaruh langsung motivasi terhadap kepuasan kerja adalah sebesar 0,317.

2. Pengembangan karir berpengaruh secara langsung dan signifikan terhadap kepuasan kerja perawat Rumah sakit dr. Soebandi Jember adalah terbukti. Pengaruh langsung pengembangan karir dengan kepuasan kerja adalah sebesar 0,316 .

3. Motivasi berpengaruh secara langsung dan signifikan terhadap kinerja perawat rumah sakit dr. Soebandi Jember adalah terbukti. Pengaruh langsung motivasi dengan kinerja adalah sebesar 0,227.

4. Pengembangan karir berpengaruh secara langsung dan signifikan terhadap kinerja perawat Rumah sakit dr. Soebandi Jember adalah terbukti. Pengaruh langsung pengembangan karir dengan kinerja adalah sebesar 0,207 
5. Kepuasan kerja berpengaruh secara langsung dan signifikan terhadap kinerja perawat Rumah sakit dr. Soebandi Jember adalah terbukti. Pengaruh langsung kepuasan kerja dengan kinerja adalah sebesar 0,369.

\section{Kesimpulan}

Hasil penelitian ini menemukan bahwa: (1) Motivasi berpengaruh secara langsung dan signifikan terhadap kepuasan kerja; (2) Pengembangan karir berpengaruh secara langsung dan signifikan terhadap kepuasan kerja; dan (3) Motivasi berpengaruh secara langsung dan signifikan terhadap kinerja Perawat rumah sakit dr. Soebandi Jember, hal ini ditunjukkan oleh koefisien jalur motivasi terhadap kinerja yang signifikan dan kuat, pengembangan karir berpengaruh secara langsung dan signifikan terhadap kinerja, kepuasan kerja berpengaruh secara langsung dan signifikan terhadap kinerja Perawat rumah sakit dr. Soebandi Jember.

\section{Saran}

Berdasarkan hasil penelitian, peneliti menyarankan bahwa untuk penelitian selanjutnya menambah variabel seperti variabel lingkungan kerja, kepemimpinan dan budaya organisasi. Selain itu masa kerja sebagai dummy variable. Juga diperkuat dengan analisis diskriminan sehingga diketahui variabel pembeda terhadap pembentuk variabel kinerja.

\section{Daftar Referensi}

Dharma. Arainta. 2007. Paradigma Baru Manajemen Sumber Daya Manusia. Dharma Books. Yogyakarta.

Faroji, Saeful. 2013. Pengaruh Kepuasan Kerja Terhadap Prestasi Kerja Karyawan Melalui Motivasi Studi Kasus pada Karyawan Pt. Columbindo Perdana Cabang Indramayu.

Gibson, James C., John M. Ivancevich, James H. Donnely Jr. 1985. Organizations, Behavior-Structure-Processes, Business Publications Inc., Piano Texas,.

Goetch. John and Davis, Keith. 1995. Human Behavior at Work. USA: Mc. Graw Hill.

Handoko, T. Hani. 2006. Manajemen Personalia dan Sumber Daya Manusia. Yogyakarta: BPFE

Hasibuan, M.S.P. 2002. Manajemen Sumber Daya Manusia: Dasar Kunci Keberhasilan. Jakarta: CV Haji Mas Agung. Jewell \& Siegall, M. (1990). Psikologi industri/organisasi modern. Jakarta: Penerbit Arcan. 
Kustiningsih. 2007. Lingkungan Kerja dan Kepuasan Kerja. Tidak dipublikasikan. Program Pascasarjana Universitas Brawijaya. Malang

Luthans, F. 1995. Organizational Behavior. Edisi 7. Singapore: Mc. Graw Hill Book. Co

Mangkunegara. 2004. Manajemen Sumber Daya Manusia. Jakarta: Bumi Aksara Jakarta.

Martoyo, Susilo. 2009. Manajemen Sumber Daya Manusia. Edisi Keempat. Yogyakarta: BPFE.

McGregor, Douglas, 1966. The Human Side of Enterprise, Mc.Graw-Hill Book Company, New York,.

Ridwan. 2004. Metode dan Teknik Menyusun Thesis. Penerbit Alfabeta Bandung.

Rivai, 2004. Manajemen Sumber Daya Manusia Untuk Perusahaan, Cetakan pertama, Penerbit Raja Grafindo Persada

Robbins, Stephen P. Mary Coulter, 2009. Management, Prentice Hall Inc., New Jersey,.

Schermerhorn Jr., John R., James G. Hunt Richard Osborn. 1991. Managing Organizational Behavior. John Wiley \& Sons. New York.

Stolovich dan Keeps. 2007. Motivation: New Directions for Theory, Research, and Practice, Academy of Management Review, Jan.

Stoner, James A.F. and Edward Freeman. 1989. Management. Front Edition. Englewood Chiffts, New Jersey : PT Bhuana IImu Populer.

Soedjono. 2005. Pengaruh Budaya Organisasi Terhadap Kinerja Organisasi dan Kepuasan Kerja Karyawan pada Terminal Umum di Surabaya. Tesis. Program Pasca Sarjana Universitas Airlangga Surabaya

Suprihatiningrum, Hesti. 2012. Faktor-Faktor Yang Mempengaruhi Prestasi Kerja.Jurnal Widyamanggala.

Wibowo, F.D. 2006. Analisis Pengaruh Kepemimpinan dan Hubungan Kerja Terhadap Pengembangan Karir dan Kepuasan Kerja Pegawai di Kantor Sekretariat Pemerintah Daerah Provinsi Bali. 